\title{
Variables related to the anticipated support for care in community- dwelling older adults ${ }^{1}$
}

\author{
Déborah Cristina de Oliveira² \\ Anita Liberalesso $\mathrm{Neri}^{3}$ \\ Maria José D’Elboux ${ }^{4}$
}

Objective: to compare the anticipated support for care, living arrangements and variables related to health as functions of gender and age in older adults in the community. Method: data was used from the Research network "Frailty in Brazilian Older Adults" (FIBRA network), sample for Campinas $(n=671)$ analyses of data description and comparison were made. Result: compared to the men, the women are in worse socio-demographic conditions and have poorer perception of their health and dependency and lower expectations of support for care; those who have expectations anticipate receiving help from only one person. Advanced age was related to lower incapacity percentages and the majority of the older adults assess their health as good or very good, irrespective of their age, although the women predominate in the group composed of those who assess their own health as bad or very bad. Conclusion: this study guides the nurse in identifying older adults in situations of risk of lack of support for care and indicates the need for interventions aiming at giving support to this group.

Descriptors: Social Support; Aged; Nursing.

\footnotetext{
${ }^{1}$ Paper extracted from master's thesis "Expectativas de suporte para o cuidado em idosos da comunidade: Dados do FIBRA-Campinas", presented to Faculdade de Enfermagem, Universidade Estadual de Campinas, Campinas, SP, Brazil. Supported by Conselho Nacional de Desenvolvimento Científico e Tecnológico (CNPq), process \# 555082/2006-7 and by Fundação de Amparo à Pesquisa do Estado de São Paulo (FAPESP), process \# 10/13969-1.

2 RN, MSc, Prefeitura Municipal de Campinas, Campinas, SP, Brazil.

${ }^{3} \mathrm{PhD}$, Full Professor, Faculdade de Educação, Universidade Estadual de Campinas, Campinas, SP, Brazil.

${ }^{4} \mathrm{PhD}$, Associate Professor, Faculdade de Enfermagem, Universidade Estadual de Campinas, Campinas, SP, Brazil.
} 


\section{Introduction}

Health conditions and well-being in old age have different outcomes depending on gender, age and social and living conditions. These can be related to functional capacity and to the perceptions of health and care in older adults ${ }^{(1)}$

Functional dependency for carrying out activities of daily living ( $A D L$ ) in older adults is normally caused by the presence of chronic illnesses, by longevity and by lack of social or health support(2). Worse self-assessments for health have also been shown to be markers for worse states of health and greater dependency and to be predictors for mortality in older adults ${ }^{(3)}$. There are also gender differences for social and health conditions and a need for care among older adults, as the majority of long-living elderly women are widows and live alone, as well as having less schooling, being frail, and having worse physical performance ${ }^{(4)}$.

The social support systems - divided into formal and informal - are essential in meeting older adults' needs. 'Formal systems', for example, encompass hospital services, long-term care facilities, and treatment at home. The informal system, or social network, on the other hand, covers networks of relationships between family members, friends, work relationships, relationships formed through living in the community, and social practices(5). In this context, taking into account the shortcomings of the public sector in relation to formal support for older adults, the family continues to represent the principal and only source of assistance for the larger part of the older adult population(6).

The anticipated support for care is a form of assessing the support perceived by the older adult, and is defined as the older adult's belief that people who are close to them will provide assistance in the future should it be necessary. This subjective evaluation, when positive, represents a better mechanism for confronting stress in old age than the actual support received by the members of the social support network. It is, therefore, considered a protective factor in facing adversities and is related to the feeling of self-efficacy in longer-lived older adults ${ }^{(7)}$

Older adults who expect support for care are less prone to functional incapacity, as the security of believing that the support will be available in the event of need seems to provide functional benefits for older adults. In addition to this, the superiority of this construct stands out in relation to support received as a way of assessing social support in older adults ${ }^{(8)}$.
In general, it is expected that informal care offered to dependent older adults should be provided by married women or a daughter ${ }^{(9)}$. In addition to this, the perception that children should care for their elderly parents has commonly been strongly influenced by cultural aspects and religion ${ }^{(10)}$. Although cultural norms and expectations vary regarding family or filial obligations, caring for an older member of the family is often seen in the context of exchanges in life and family solidarity ${ }^{(11)}$. Spouses, for example, frequently mention the fulfilling of marital vows, while adult children speak of repaying their parents who took care of them when they themselves were younger.

In one study undertaken with 1,005 Brazilian older adults ${ }^{(12)}$ it was ascertained that the informal care undertaken by family carers - on whom the majority of older adults expect to be able to rely in their old age is slowly ceasing to exist, as social changes and families' economic changes increase. The world population is facing a 'global care crisis', which may impact all societies, unless individuals and governments begin to prepare for it.

The Research Network on Frailty in Brazilian Older Adults (FIBRA Network), a multi-centric study group dedicated to the phenomenon of frailty in older adults in the community, addressed the issue of the degree of older adults' dependency for undertaking ADL, and their anticipated support for care, that is the presence of somebody to help them should they come to need it, in order to assess the degree of limitation presented by the older adults and the assistance available as perceived by the older adult(13).

This being the case, it was sought to compare the anticipated support for care, living arrangements, and variables related to health, as functions of gender and age range, in older adults in Campinas, São Paulo. It is anticipated that the results presented here may guide nurses in identifying older adults in situations of risk, offering support for the preparation of strategies seeking to reduce and even to meet the older adults' care needs and the needs of their families, and in the search for new assistance resources.

\section{Method}

This cross-sectional study was undertaken based on data from the city of Campinas in the State of São Paulo, Brazil, obtained from the Research Network on Frailty in Brazilian Older Adults (FIBRA Network). This network's focus is on studying the phenomenon of frailty in the Brazilian elderly population, and its relationships with socio-demographic, psychological, health and care 
variables ${ }^{(14)}$. The inclusion criteria were: to be aged 65 or over, to understand the instructions, to agree to participate, and to be a permanent resident in the home and census sector. People were considered to be ineligible for the research if: a) problems of memory, attention, spatial or temporal orientation or communication were present, suggestive of serious cognitive deficit; b) permanent or temporary inability to walk, use of walking sticks or walking frames being permitted, but not wheel-chairs; c) localized loss of strength or aphasia resulting from serious cerebrovascular accidents; d) serious compromising of motor skills, speech or emotion associated with Parkinson's Disease at an advanced or unstable stage; e) serious disabilities in hearing or vision, strongly hindering communication, and f) older adults at the end of life. For the present study, the fact of the older adult having responded to the questions related to variables of interest was included as another inclusion criteria. Of the 835 older adults interviewed in Campinas, 671 matched the inclusion criteria, and were selected for the present study.

Data collection took place between September 2008 and June 2009, in single sessions lasting between 40 and 120 minutes, following signature of the Terms of Free and Informed Consent in a format approved by the Research Ethics Committee of the Unicamp Faculty of Medical Sciences (208/2007). This was followed by questionnaires of identification and of socio-demographic data, the Mini-Mental State Examination (MMSE), measurements of blood pressure and anthropometric measurements, collection of blood specimens, mouth cavity examination and measurements for the frailty phenotype. Performance superior to the cut-off point obtained in the MMSE was adopted for the older adults' participation in the other measurements. The present study's variables were investigated under the conditions presented in Figure 1.

\begin{tabular}{|c|c|c|c|c|}
\hline Variável & Questão & Tipo de variável & \multicolumn{2}{|c|}{ Alternativas de resposta } \\
\hline Gênero & - & Independente, nominal. & \multicolumn{2}{|l|}{ Masculino; feminino } \\
\hline Age & - & $\begin{array}{l}\text { Independent, numerical } \\
\text { and continuous, later } \\
\text { categorized. }\end{array}$ & \multicolumn{2}{|c|}{$\begin{array}{l}\text { Recorded as a continuous variable, tabulated in ranges from } 65 \text { to } \\
74 \text { years and } 75 \text { years and over. }\end{array}$} \\
\hline $\begin{array}{l}\text { Living } \\
\text { arrangements }\end{array}$ & "With whom do you live?" & $\begin{array}{l}\text { Independent and } \\
\text { nominal. }\end{array}$ & $\begin{array}{l}\text { They marked all that were applicable: } \\
\text { yes; no. Next, they responded to the } \\
\text { options: alone; w/ spouse; w/ son/ } \\
\text { daughter; w/ grandson/daughter; w/ } \\
\text { great-grandson/daughter; w/ another } \\
\text { relative; w/ persons from outside the } \\
\text { family. }\end{array}$ & $\begin{array}{l}\text { For analysis of the data, } \\
\text { two categories were } \\
\text { created: lives alone; lives } \\
\text { accompanied. }\end{array}$ \\
\hline $\begin{array}{l}\text { Anticipated } \\
\text { support for care } \\
\text { for undertaking } \\
\text { BADL and IADL }\end{array}$ & $\begin{array}{l}\text { "Should you need help } \\
\text { to carry out any of these } \\
\text { activities, is there somebody } \\
\text { you can rely on?" }\end{array}$ & $\begin{array}{l}\text { Dependent, } \\
\text { dichotomous and } \\
\text { nominal. }\end{array}$ & $\begin{array}{l}\text { Yes; no. If 'yes', it was asked who the } \\
\text { person was. The older adult indicated } \\
\text { the alternatives matching his or her } \\
\text { reality. }\end{array}$ & $\begin{array}{l}\text { If yes, classified as: one } \\
\text { person; two or more } \\
\text { persons. }\end{array}$ \\
\hline $\begin{array}{l}\text { Perceived } \\
\text { health }\end{array}$ & $\begin{array}{l}\text { "Generally, how would you } \\
\text { evaluate your health at the } \\
\text { moment?" }\end{array}$ & $\begin{array}{l}\text { Independent, } \\
\text { categorical and ordinal. }\end{array}$ & \multicolumn{2}{|c|}{ Excellent; very good; good; normal; very bad } \\
\hline $\begin{array}{l}\text { Self-reported } \\
\text { illnesses }\end{array}$ & \multicolumn{2}{|c|}{$\begin{array}{l}\text { "In the last } 12 \text { months, has a doctor told you that you } \\
\text { have any of the following health problems?" }\end{array}$} & $\begin{array}{l}\text { Independent and nominal, later } \\
\text { categorized. }\end{array}$ & $\begin{array}{l}\text { For each illness cited, } \\
\text { responded: yes; no. } \\
\text { The variable was later } \\
\text { categorized as } 0-2 ; \geq 3 \\
\text { illnesses. }\end{array}$ \\
\hline \multirow{3}{*}{$\begin{array}{l}\text { Functional } \\
\text { independence }\end{array}$} & $\begin{array}{l}\text { Advanced Activities of Daily } \\
\text { Living (AADL) }\end{array}$ & $\begin{array}{l}\text { "What is your } \\
\text { relationship with the } \\
\text { following activities:" }\end{array}$ & Categorical and numerical & $\begin{array}{l}\text { For each activity: never } \\
\text { done; stopped doing; still } \\
\text { does. Activities which } \\
\text { they had "stopped doing" } \\
\text { taken into account. }\end{array}$ \\
\hline & $\begin{array}{l}\text { Instrumental Affinities Daily } \\
\text { Living (IADL) }\end{array}$ & $\begin{array}{l}\text { "Is totally independent, } \\
\text { needs some help, or } \\
\text { needs total help so } \\
\text { as to do each of the } \\
\text { following things:" }\end{array}$ & Categorical and numerical. & $\begin{array}{l}\text { Totally independent; } \\
\text { needs some help; needs } \\
\text { total help. Activities which } \\
\text { they had "stopped doing" } \\
\text { taken into account }\end{array}$ \\
\hline & $\begin{array}{l}\text { Basic Activities of Daily } \\
\text { Living (BADL) }\end{array}$ & $\begin{array}{l}\text { "Is totally independent, } \\
\text { needs some help or } \\
\text { needs total help to do } \\
\text { each of the following } \\
\text { things:" }\end{array}$ & Categorical and numerical. & $\begin{array}{l}\text { Totally independent; } \\
\text { needs some help; needs } \\
\text { total help. Activities which } \\
\text { they had "stopped doing" } \\
\text { taken into account. }\end{array}$ \\
\hline
\end{tabular}

Figure 1 - Operational characterization of the variables. Campinas, São Paulo, Brazil, 2012 
Descriptive frequency analysis was carried out on the categorical variables, with values of absolute frequency (n) and relative distribution (\%), and descriptive statistics of the numerical variables, with mean values, standard deviation, and minimum and maximum values. For comparison of the principal categorical variables between gender and age range, the Chi-Squared or Fisher's Exact tests were used. The level of significance adopted for the statistical tests was $5 \%$.

\section{Results}

Of the 900 older adults who participated in the FIBRA Study's first phase of data collection, 689 attained a score above the cut-off point for the MMSE and were included in the second phase of data collection. Of these, 671 answered all the present study's questions of interest and thus made up the final sample described below.

Most of the older adults were women (68.70\%), aged between 65 and 90, with the mean (sd) of 72.31
(5.33) and the median of 72 years. Over half of the older adults (57.10\%) had none, one or two illnesses. Of these, approximately $11 \%$ denied having any illness. Around $60 \%$ assessed their health as "good" or "very good".

Generally, the older adults had good functional performance, maintaining their independence for undertaking IADL (74.14\%) and BADL (89.47\%). However, $94.10 \%$ of the older adults indicated at least one ADL to be compromised and $92.23 \%$ had stopped undertaking at least one AADL. The majority live with somebody (83.91\%) and reported anticipating support for care $(89.12 \%)$, with $44 \%$ expecting to receive care from one person, and a similar number of older adults expecting it from two or more persons.

On comparing the variables of interest as functions of gender, a higher number of women live alone (20.52\%) and have a greater number of illnesses (49.02\%). When compared with the men, they have a greater number of inabilities in BADL (12.42\%) and worse evaluation of their own health $(7.39 \%)$ (Table 1$)$.

Table 1 - Comparative analysis of the variables of interest to the study, as functions of gender $(n=671)$. Campinas, SP, Brazil, 2008-2009

\begin{tabular}{|c|c|c|c|}
\hline \multirow{3}{*}{ Variable } & \multicolumn{2}{|c|}{ Gender - n (\%) } & \multirow{3}{*}{ p-value } \\
\hline & Male & Female & \\
\hline & $\mathrm{n}=210(100 \%)$ & $\mathrm{n}=461(100 \%)$ & \\
\hline Age & & & 0.221 \\
\hline $65-74$ & $152(72.38)$ & $312(67.68)$ & \\
\hline$\geq 75$ & $58(27.62)$ & $149(32.32)$ & \\
\hline Living arrangements & & & $<0.001$ \\
\hline Alone & $13(6.28)$ & $94(20.52)$ & \\
\hline Accompanied & $194(93.72)$ & $364(79.48)$ & \\
\hline Anticipated support for care & & & 0.018 \\
\hline Yes & $196(93.33)$ & $402(87.20)$ & \\
\hline No & $14(6.67)$ & $59(12.80)$ & \\
\hline \multicolumn{4}{|l|}{ Number of people } \\
\hline Absence of expectation & $14(6.80)$ & $59(12.85)$ & $<0.001$ \\
\hline 1 & $78(37.86)$ & $215(46.84)$ & \\
\hline$\geq 2$ & $114(55.34)$ & $185(40.31)$ & \\
\hline Number of illnesses & & & $<0.001$ \\
\hline $0-2$ & $147(70.67)$ & $235(50.98)$ & \\
\hline$\geq 3$ & $61(29.33)$ & $226(49.02)$ & \\
\hline Perceived Health & & & 0.04 \\
\hline Bad and very bad & $5(2.42)$ & $34(7.39)$ & \\
\hline Normal & $76(36.71)$ & $160(34.78)$ & \\
\hline Good and very good & $126(60.87)$ & $266(57.83)$ & \\
\hline \multicolumn{4}{|l|}{ Incapacity } \\
\hline - For BADL & & & 0.018 \\
\hline No activity & $193(93.69)$ & $402(87.58)$ & \\
\hline$\geq 1$ & $13(6.31)$ & $57(12.42)$ & \\
\hline
\end{tabular}


Table 1 - (continuation)

\begin{tabular}{|c|c|c|c|}
\hline \multirow{3}{*}{ Variable } & \multicolumn{2}{|c|}{ Gender - n (\%) } & \multirow{3}{*}{$p$-value } \\
\hline & Male & Female & \\
\hline & $n=210(100 \%)$ & $n=461(100 \%)$ & \\
\hline - For IADL & & & 0.627 \\
\hline No activity & $156(75.36)$ & 337 (73.58) & \\
\hline$\geq 1$ & $51(24.64)$ & $121(26.42)$ & \\
\hline - For AADL & & & 0.031 \\
\hline No activity & $9(4.41)$ & $42(9.29)$ & \\
\hline$\geq 1$ & $195(95.59)$ & $410(90.71)$ & \\
\hline - General incapacity & & & 0.064 \\
\hline No activity & $7(3.38)$ & $32(7.05)$ & \\
\hline$\geq 1$ & 200 (96.62) & 422 (92.95) & \\
\hline
\end{tabular}

The percentage of men who stopped undertaking some AADL (95.59\%) was greater than that of women, just as the anticipated support for care was more present in the men (93.33\%). The number of persons from whom care was expected to be received was also greater among the men (55.34\%), with the majority of the women expecting to receive help from only one person (46.84\%).

In the comparison of the same variables as functions of age ranges, it was found that $22.55 \%$ of the more elderly older adults live alone and have inabilities for the IADL (35.96\%) (Table 2).

Table 2 - Comparative analysis of the variables of interest to the study, as functions of age $(n=671)$. Campinas, SP, Brazil, 2008-2009

\begin{tabular}{|c|c|c|c|}
\hline \multirow{3}{*}{ Variable } & \multicolumn{2}{|c|}{ Age Range - n (\%) } & \multirow{3}{*}{$\mathrm{p}$-value } \\
\hline & $65-74$ years & $\geq 75$ years & \\
\hline & $n=461(100 \%)$ & $n=204(100 \%)$ & \\
\hline Living arrangements & & & 0.003 \\
\hline Alone & $61(12.23)$ & $46(22.55)$ & \\
\hline Accompanied & $400(86.77)$ & $158(77.45)$ & \\
\hline Anticipated support for care & & & 0.691 \\
\hline Yes & $415(89.44)$ & $183(88.41)$ & \\
\hline No & 49 (10.56) & $24(11.59)$ & \\
\hline Number of persons & & & 0.918 \\
\hline Absence of expectation & $49(10.65)$ & $24(11.71)$ & \\
\hline 1 & $204(44.35)$ & $89(43.41)$ & \\
\hline$\geq 2$ & $207(45.00)$ & $92(44.88)$ & \\
\hline Number of illnesses & & & 0.402 \\
\hline $0-2$ & $260(56.03)$ & $122(59.51)$ & \\
\hline$\geq 3$ & $204(43.97)$ & $83(40.49)$ & \\
\hline Perceived health & & & 0.37 \\
\hline Very bad and bad & $30(6.48)$ & $9(4.41)$ & \\
\hline Normal & $168(36.29)$ & $68(33.33)$ & \\
\hline Good and very good & $265(57.24)$ & $127(62.25)$ & \\
\hline \multicolumn{4}{|l|}{ Incapacity } \\
\hline For IADL & & & $<0.001$ \\
\hline No activity & $363(78.57)$ & $130(64.04)$ & \\
\hline$\geq 1$ & $99(21.43)$ & $73(35.96)$ & \\
\hline For AADL & & & 0.447 \\
\hline No activity & $38(8.30)$ & $13(6.57)$ & \\
\hline$\geq 1$ & $420(91.70)$ & $185(94.43)$ & \\
\hline For BADL & & & 0.47 \\
\hline 0 & $416(90.04)$ & $179(88.18)$ & \\
\hline$\geq 1$ & $46(9.96)$ & $24(11.82)$ & \\
\hline
\end{tabular}


Table 2 - (continuation)

\begin{tabular}{|c|c|c|c|}
\hline \multirow{3}{*}{ Variable } & \multicolumn{2}{|c|}{ Age Range - n (\%) } & \multirow{3}{*}{$p$-value } \\
\hline & $65-74$ years & $\geq 75$ years & \\
\hline & $n=461(100 \%)$ & $n=204(100 \%)$ & \\
\hline General incapacity & & & 0.305 \\
\hline No activity & $30(6.52)$ & $9(4.48)$ & \\
\hline$\geq 1$ & 430 (93.48) & $192(95.52)$ & \\
\hline
\end{tabular}

\section{Discussion}

In line with the criteria for participation in the present study, older adults were selected whose cognitive framework was preserved and whose functional capacity was, on the whole, also preserved. It should be emphasized, therefore, that older adults who are restricted to their homes or who have greater physical or cognitive limitations were not considered, nor were their anticipated support for care.

In spite of this, it was possible to identify statisticallysignificant differences in relation to gender and age range in this sample relating to the variables studied, with the women being in worse socio-demographic conditions, and having worse perceptions of health and care than older men. The women represent the majority in this populational study, reaffirming the issue of the feminization of old age in Brazil(15) and in other countries $^{(16)}$, which is accompanied by a higher number of women living alone(17), a higher number of chronic illnesses and poorer functional indexes, in line with what was obtained in the female group ${ }^{(18)}$. This data is directly related to probable low quality of life, influenced by the majority of Brazilian older adults' low levels of schooling, poor economic conditions, and the presence of incapacities.

Older adults with a greater number of chronic illnesses have a higher risk of becoming dependent for $A D L^{(2)}$, with the worse functional indexes being present in the women, as indicated by the data from the National Household Sample Survey (PNAD) of 1998 to $2008^{(19)}$. The literature shows that being female has been considered an independent risk factor for functional decline and that one of the reasons is the fact that women have a greater life expectancy and are subject to a larger number and wider variety of chronic illnesses, through experiencing worse socio-economic conditions than men, which limits access to care and changes in health behaviors(20).

The anticipated support for care, and the number of persons from whom the older adult expects to receive help, are associated with gender, which means that the women have an absence of anticipated support for care should they come to need help. Those women who do have the expectation anticipate receiving help from only one person, which in most cases is their companion, who is also elderly.

Elderly women are the principle carers for their spouses, but are less likely to receive care from the family. This is one of the factors which help to explain why, in general, women predominate in long-term care facilities. Therefore, if they live in conditions of poverty, they do not have anticipated support for care or means to pay for the service(9).

In a study undertaken with 1,103 older adults in the USA, elderly women presented worse functional conditions and anticipated support for care ${ }^{(21)}$. The authors concluded that the older women who did have this anticipation were less prone to have functional incapacity in comparison with those who did not. This may explain the fact that the women in the present study have worse health conditions and lack anticipated support when compared to the men.

The functional incapacity in AADL, IADL, and BADL is hierarchically related to the age ranges. That is, the more long-lived somebody is, the worse their functional capacity is, proportionally. This is another explanation for the worse indexes of women's functional performance, evidenced in the present study, especially in BADL these women live longer, but experience more years with incapacity. These results confirm that, although the women live longer than the men, they pass through a greater period of physical incapacity before dying(22).

The present study also showed that the majority of the older adults assessed their health as good or very good, which is consistent with findings in the literature ${ }^{(16)}$. There was no significant difference for the different age groups in self-assessment of health. However, regarding gender, the women head the group which assesses its health as bad or very bad.

In a study carried out in São Paulo on the determinant factors for self-perception of health ${ }^{(1)}$, the 
odds of self-assessing health as bad were $16 \%$ higher for women. The chances of older adults reporting poor health were higher in all the age groups, but fell with advancing age. Older adults who lived alone evaluated their health more positively in relation to those who lived accompanied, even after controlling for the variables of sex and age. The presence of chronic illnesses associated with gender was the determinant most strongly related to self-perception of health, with - for men - the presence of four or more chronic illnesses implying a risk ten times larger of self-perception of health as bad. For the women, this risk was about eight times higher. In the absence of, or even in the presence of two or more chronic illnesses, the older women had a higher probability of reporting a good self-perception of health in comparison with the men.

Considering that a self-assessment of health as bad is significantly associated with mortality, the women in the present study are at a disadvantage, in the sense that they are more vulnerable to the development of illnesses, which added to the lack of expectation of support for care leads to a higher risk of mortality.

The present study's limitations are related to the lack of information regarding the type of care or family relationships. It was possible, however, to ascertain the relevance of investigating the social context and expectation of support for care of the older adults living in the community for the nurses' practice, and to ascertain that the strengthening of the support networks for older adults is fundamental.

\section{Conclusion}

This study guides the nurse in understanding how gender, age, perception of health and living arrangements in old age can be related to the anticipated support for care. It is concluded that the older adults' anticipated support for care in Campinas, São Paulo, is related to gender, and is independent of age. Other variables demonstrated that the older adults do not consider themselves well in relation to the perception of health and care, being susceptible to functional decline and lack of support. This characterizes the demand for care as being preponderantly female, however, it is the women who do not anticipate care.

Policies and initiatives which aim to give support to these older adults and their families are shown to be necessary, as the older adults must be assured of their right to be cared for. Further research is necessary investigating Brazilian older adults' expectation of support for care, and forms of support received, such that other aspects related to this variable in different populational groups may be understood.

\section{References}

1. Alves LC, Rodrigues RN. Determinantes da autopercepção de saúde entre idosos do Município de São Paulo, Brasil. Rev Panam Salud Publica. 2005;17(56):333-41.

2. Rosset I, Roriz-Cruz M, Santos LF, Haas VJ, FabrícioWehbe SCC, Rodrigues RAP. Diferenciais socioeconômicos e de saúde entre duas comunidades de idosos longevos. Ver. Saúde Pública. 2011;45(2):391-400.

3. Sargent-Cox KA, Anstey KJ, Luszcz MA. The choice of self-rated health measures matter when predicting mortality: evidence from 10 years follow-up of the Australian longitudinal study of ageing. BMC Geriatr. 2010;10:18.

4. Duarte YAO. Desempenho funcional e demandas assistenciais. In: Lebrão $\mathrm{ML}$, Duarte YAO. O projeto SABE no município de São Paulo: uma abordagem inicial; 2003. p. 183-200.

5. Bocchi SCM, Angelo M. Between freedom and reclusion: social support as a quality-of-life component in the family caregiver-dependent person binomial. Rev. Latino-Am. Enfermagem. 2008;16(1):15-23.

6. Antonucci, TC, Birditt KS, Sherman CW, Trinh S. Stability and change in the intergerational family: a convoy approach. Ageing and Society. 2011;31(7):1084106.

7. Krause N. Longitudinal study of social support and meaning in life. Psychol Aging. 2007;22(3):456-69.

8. Shaw BA, Janevic M. Representative Sample of Older Adults. J Aging Health. 2004;16(4):539-61.

9. Giacomin KC, Uchoa E, Lima-Costa MFF. Projeto Bambuí: a experiência do cuidado domiciliário por esposas de idosos dependentes. Cad. Saúde Pública. 2005;21(5):1509-18.

10. De Valk HAG, Saad PM. Perceptions of filial obligation among migrant and non-migrant elderly: a comparison at the country of origin and destination. European Population Conference; 2008.

11. Katz R, Lowenstein A, Phillips J, Daatland SO. Theorizing intergenerational family relations: solidarity, conflict and ambivalence in cross-cultural contexts. In: Benston VL, Acock AC, Allen KR, Dillworth-Anderson $P$, Klein DM (org). Sourcebook of Family Theory and Research. Thousand Oaks (CA): Sage. 2005; p.393-420. 
12. BUPA. Bupa Health Pulse, 2010. [disponível em: http://www.bupa.com/about-us/information-centre/ bupa-health-pulse-2010].

13. Fontes AP, Fortes-Burgos ACG, Mello DM, Pereira AA, Neri AL. Arranjos domiciliares, expectativa de cuidado, suporte social percebido e satisfação com as relações sociais. In: Neri AL, Guariento ME (org.). Fragilidade, saúde e bem-estar em idosos: dados do estudo FIBRA Campinas. Campinas (SP): Alínea. 2011; p.55-74.

14. Neri AL, Yassuda MS, Fortes-Burgos ACG, Mantovani EP, Arbex FS, Torres AVS, et al. FIBRA Campinas: fundamentos e metodologia de um estudo sobre fragilidade em idosos da comunidade. In: Neri $A L$, Guariento ME (org.): Fragilidade, saúde e bem-estar em idosos: dados do estudo FIBRA Campinas. Campinas (SP): Alínea. 2011. p.27-54.

15. Muranetti DB, Barbosa AR, Marucci MFN, Lebrão ML. Hipertensão arterial referida e indicadores antropométricos de gordura em idosos. Rev. Assoc. Med. Bras. 2011;57(1):25-30.

16. Arai $Y$, Iinuma T, Takayama M, Takayama M, Abe $Y$, Fukuda $R$, et al. Study protocol The Tokyo Oldest Old Survey on Total Health (TOOTH): A longitudinal cohort study of multidimensional components of health and well-being. BMC Geriatrics. 2010;10(35):1-11.

17. Pedrazzi EC, Motta TTD, Vendrúsculo TRP, FabrícioWehbe SCC, Cruz IR, Rodrigues RAP. Household arrangements of the elder elderly. Rev. Latino-Am. Enfermagem. 2010;18(1):18-25.

18. Lebrão $M L$, Laurenti R. Condições de saúde. In Lebrão ML, Duarte YAO. SABE-Saúde, Bem-estar e Envelhecimento. O Projeto SABE no Município de São Paulo: Uma abordagem inicial. Organização PanAmericana da Saúde: Brasília (DF); 2003. p.73-92.

19. Camarano AA, Kanso S. Como as famílias brasileiras estão lidando com idosos que demandam cuidados e quais as perspectivas futuras? A visão mostrada pelas PNADs. In: Camarano AA (org.). Cuidados de longa duração para a população idosa: um novo risco social a ser assumido? Rio de Janeiro: Instituto de Pesquisa Econômica Aplicada-Ipea; 2010. p.93-122.

20. Ostchega Y, Harris TB, Hirsch R, Parsons VL, Kington $R$, Katsoff M. Reliability and prevalence of physical performance examination assessing mobility and balance in older persons in the US: data from the third National and Nutrition Examination Survey. J Am Geriatr Soc. $2000 ; 48(9): 1136-41$.
21. Shaw B. Anticipated Support From Neighbors and Physical Functioning During Later Lifes. Research on aging. 2005;27(5):503-25.

22. Camargos MCS, Rodrigues RN, Machado CJ. Idoso, família e domicílio: uma revisão narrativa sobre a decisão de morar sozinho. Rev. bras. estud. popul. $2011 ; 28(1): 217-30$. 